\title{
Japan's funding cuts hit the future of science
}

\section{Raising the cost of postgraduate education is likely to exclude many promising students.}

Sir - Since Prime Minister Junichiro

Koizumi initiated structural reforms, the research system in Japan has prepared for extensive and rapid changes (see Nature 412, 364; 2001). In August, Koizumi's cabinet proposed a reduction in the national scholarship fund managed by the Japan Scholarship Foundation (JSF). The main components of the plan, to be implemented by 2005, are a reduction in interest-free loans, transfer of low-interest (3\% per year) loans to the private sector, and abolition of repayment exemptions for scientists in the public research sector. Last month, abolition of JSF itself was added to this plan. In the budget plan for fiscal year 2002 , there is a proposal to cut the number of interest-free loans and to reduce the total JSF budget by $9.9 \%$.

In 2000, one-third of the graduate student population $(75,290)$ received JSF scholarships and $66 \%$ of scholarship students received interest-free loans. The new scheme will hamper the ability of students to cover living expenses because most scholarship students will have to repay loans with interest, which could reach more than $¥ 6$ million (US\$50,000) by the time they leave graduate school.

Like the merger of Japan's three main space programmes and research institutions (see Nature 412, 843; 2001), the new proposal has shocked researchers and students.

The national scholarship system in Japan is poor compared with those in the United States and the United Kingdom. For example, there are few private scholarships, and the average JSF scholarship (about $¥ 1.2$ million or US $\$ 10,000$ a year) does not cover tuition and living expenses. A graduate science student on a stipend could expect roughly US\$15,000-20,000 per year plus payment of tuition fees in the United States or $\mathfrak{E} 10,000$ (US\$15,000) a year in the United Kingdom - though of course there is competition for these. But in Japan, most students work part time and/or depend on their parents' financial support to supplement meagre government support.

Even so, JSF scholarships are the major source of funding for graduate students. One institute that aids promising young researchers, the Japan Society for the Promotion of Science, is increasing its numbers of $\mathrm{PhD}$ fellowships. But currently, only $5 \%$ of $\mathrm{PhD}$ students are recipients. In June, the government announced a plan to improve the stipend system, winning approval from graduate students. Not only has this plan not yet taken shape, however, but a reduction is already being implemented.

A national scholarship scheme that burdens graduate students will impede the progress of research in Japan. I foresee a time when only the rich can attend graduate school and many promising students will be excluded. Not only will students lack opportunity, but our country will be unable to maintain the quality of its research. If Japan wants to maintain and even advance its status in science and technology, it should expand rather than reduce financial aid for graduate study. The government should remember that although national investment in education and research shows no short-term results, it is a wise long-term investment. Eisuke Enoki

School of Medicine, Faculty of Medicine, Kobe University, Kusunokicho 7-5-1, Chuo-ku, Kobe, Hyogo 650-0017, Japan

\section{Could sale of fossils be the key to ending theft?}

Sir - Although the federal legislation being prepared to safeguard the fossil record may attain some of the wished-for goals described in your News story "US lays out bare bones of fossil protection package" (see Nature 413, 555; 2001), experience and theory suggest that fossil theft from federal lands will continue.

Assuming there is strict enforcement, criminalizing the unauthorized removal of fossils and increasing penalties may reduce pillaging in the short run, but over the long term the trade in looted archaeological and other cultural property has increased since efforts started being made to control it.

Black markets for palaeontological specimens continue to flourish in China (see Nature 406, 930-932; 2000) despite central government efforts to crack down on fossil smuggling. Colin Renfrew, professor of archaeology at the University of Cambridge, has concluded that 30 years after the adoption of the 1970 UNESCO convention to halt the illicit trade in cultural property, the destruction of archaeological sites through looting has increased rather than diminished (see Trade in Illicit Antiquities, eds N. Brodie et al., xi-xii; McDonald Institute for Archaeological Research, Cambridge, 2001).

Price theory suggests that a divergence between a market price and an officially imposed price (because the legal sale of fossil specimens on federal lands is prohibited, the price is close to zero) fosters a black market and creates incentives for theft and looting, resulting in a permanent loss to our knowledge of the fossil record. In other sectors of society, creating a market and a price for a resource that had previously been cost-free, such as clean air, has resulted in conservation of the good, in this instance reflected in a sharp fall in air pollution from coal-fired power plants in the American Midwest.

Applying the profit mechanism and market incentives to the management of palaeontological resources could similarly result in the improved conservation and preservation of the fossil record.

\section{Edward Krowitz}

98 Riverside Drive, Apt. 7E, New York,

New York 10024, USA

\section{Messenger RNA: origins of a discovery}

Sir - In his review of James Watson's Genes, Girls and Gamow (see Nature 413, 775-776; clarification Nature 414, 487; 2001), Horace Judson attributes the discovery of messenger RNA to François Jacob, Sydney Brenner and Matthew Meselson.

In fact, Jacob, Brenner and Francis Crick, at an informal meeting on Good Friday 1960, suddenly 'discovered' the unique RNA found first in 1956 by Elliot Volkin and Lazarus Astrachan. Good accounts of this event can be found in The Statue Within by Jacob and What Mad Pursuit by Crick.

In several publications in 1958, Volkin and Astrachan thoroughly described the unusual properties of this RNA, which they termed DNA-like RNA. These were precisely the properties that Jacob and Jacques Monod sought to assign to the unstable intermediate (which they called $\mathrm{X}$ ), necessary for the synthesis of galactosidase.

Out of that Good Friday discussion on the lactose operon came the realization that Volkin and Astrachan's DNA-like RNA was indeed the genetic messenger, hence messenger RNA (mRNA).

\section{Alvin M. Weinberg}

Oak Ridge Associated Universities, PO Box 117,

Oak Ridge, Tennessee 37831-0117, USA 